\title{
Phospholipase A2
}

National Cancer Institute

\section{Source}

National Cancer Institute. Phospholipase A2. NCI Thesaurus. Code C104973.

Phospholipase A2 (148 aa, $16 \mathrm{kDa}$ ) is encoded by the human PLA2G1B gene. This protein plays a role in fatty acid metabolism. 